\title{
Status Fisiologis Kambing Peranakan Etawah Laktasi yang Diberi Ransum Berbasis Ampas Kurma
}

\section{(Physiologis Statue of Lactating Cross Breed Goats Fed Ration Containing Date Fruit Waste)}

\author{
Tresia GE ${ }^{1}$, Evvyernie D ${ }^{2}$ \\ ${ }^{1}$ Pusat Penelitian dan Pengembangan Peternakan, Jl. Raya Pajajaran Kav E59 Bogor 16128 \\ ${ }^{2}$ Departemen Nutrisi dan Teknologi Pakan, Fakultas Peternakan, Institut Pertanian Bogor \\ gresyeva@gmail.com
}

\begin{abstract}
Feeds with different energy sources can affect the physiological conditions of Etawah Crossbreed (EC) goats due to differences in the fermentation process or feed metabolism in livestock bodies. The purpose of this research was to study the effect of supplementation of Dates Fruit Waste (DFW) in goat ration on feed addition in the ration on performace and physiological responses of Etawah crossbreed goats (rectal temperature, respiratory rate, and heart rate). The experimental design was a randomized block design using 9 primiparous lactating dairy goats. There were three types of ration as treatments used in this study, i.e. R0= $35 \%$ forage $+65 \%$ concentrate, $\mathrm{R} 1=35 \%$ forage $+55 \%$ concentrate $+10 \% \mathrm{DFW}$, and $\mathrm{R} 2=$ $35 \%$ forage $+45 \%$ concentrate $+20 \%$ DFW. The results showed that supplementation dates fuit waste has no effect on rectal temperature, respiratory rate, and heart rate frequency. The average rectal temperature, respiratory rate, and heart rate of EC goats were $38.62-29.04^{\circ} \mathrm{C}$, 27.27-58.13 times/min and 81.11-91.05 times/min, respectively. It can be used as an alternative feed for the lactating dairy goat up to $10 \%$ in the ration
\end{abstract}

Key words: Dates fruit waste, energy sources, physicology responses

\begin{abstract}
ABSTRAK
Pakan dengan sumber energi yang berbeda dapat mempengaruhi kondisi fisiologis kambing PE karena perbedaan proses fermentasi atau metabolisme pakan dalam tubuh ternak. Penelitian ini bertujuan untuk mengkaji pengaruh kualitas pakan terhadap respon fisiologis kambing peranakan etawah yang diberi ampas kurma. Rancangan percobaan yang digunakan adalah rancangan acak kelompok (RAK) dengan 9 ekor kambing perah laktasi yang telah sekali beranak. Ransum perlakuan yang digunakan terdiri atas $\mathrm{T} 0=35 \%$ hijauan $+65 \%$ konsentrat, $\mathrm{T} 1=35 \%$ hijauan $+55 \%$ konsentrat $+10 \%$ ampas kurma, dan $\mathrm{T} 2=35 \%$ hijauan + $45 \%$ konsentrat $+20 \%$ ampas kurma. Rancangan percobaan yang digunakan adalah rancangan acak kelompok dengan 3 perlakuan dan 3 ulangan. Parameter yang diamati adalah respon fisiologis meliputi suhu rektal, frekuensi respirasi dan denyut nadi. Hasil penelitian menunjukkan bahwa suplementasi ampas kurma tidak berpengaruh terhadap respon fisiologis ternak. Respon fisiologis kambing PE hasil penelitian dalam kondisi normal. Rata-rata denyut nadi, frekuensi respirasi dan suhu rektal kambing PE berturut-turut 27,27-58,13 kali/menit, $81,11-91,05 \mathrm{kali} / \mathrm{menit}$ dan $38,62-39,04^{\circ} \mathrm{C}$. Berdasarkan hasil penelitian dapat disimpulkan bahwa ampas kurma dapat dijadikan sebagai alternatif pakan kambing perah dengan penggunaan hingga 10\% di dalam ransum.
\end{abstract}

Kata kunci: Ampas kurma, pakan sumber energi, respon fisiologis 


\section{PENDAHULUAN}

Populasi penduduk Indonesia yang semakin meningkat dan kesadaran terhadap pentingnya pemenuhan gizi protein hewani menyebabkan permintaan produk asal ternak terus meningkat. Salah satu produk asal ternak yang permintaannya tinggi adalah susu kambing. Di Indonesia, kambing Peranakan Etawah (PE) telah banyak dipelihara sebagai ternak penghasil susu karena memiliki kemampuan adaptasi tinggi terhadap lingkungan tropis. Produktivitas susu kambing PE berkisar 0,5 liter hingga 2 liter/ekor/hari (Sutama 2011). Permasalahan yang ditemukan di peternakan kambing perah adalah konsentrat untuk kambing perah belum diproduksi secara khusus, sehingga peternak masih harus menggunakan konsentrat sapi perah dan beralih ke jenis pakan asal produk samping agroindustri. Padahal peningkatan produktivitas ternak kambing perah seyogyanya perlu didukung, salah satunya dengan perbaikan kualitas dan kuantitas pakan. Badan Pusat Statistik (2017) mencatat imbangan biaya pakan sebesar 29,97\% (8,31\% hijauan, 3,49\% pakan buatan pabrik dan pakan lainnya $18,17 \%$ ) dari total biaya produksi usaha kambing per ekor skala rumah tangga.

Pakan mengandung zat nutrisi berupa karbohidrat, protein, lemak, vitamin dan mineral yang bermanfaat bagi pertumbuhan dan produktivitas ternak. Pakan dengan sumber energi yang berbeda dapat mempengaruhi kondisi fisiologis ternak karena perbedaan proses fermentasi atau metabolisme pakan dalam tubuh ternak. Ampas kurma merupakan bahan pakan yang tinggi akan kandungan energi. Ampas kurma merupakan by product industri sari kurma dan dapat dihasilkan mencapai 56\% dari total daging kurma yang diolah per harinya. Salah satu pabrik di Bogor menghasilkan ampas kurma sebanyak 1,4 ton/hari atau 504 ton/tahun (Yuniarti 2016). Jumlah yang melimpah ini sangat potensial untuk dimanfaatkan sebagai pakan. Ampas kurma mengandung BK 16,9628,71\%; PK 8,01-9,71\%; LK 1,28-1,33\%; SK 16,48-20,70\%; BETN 66,78-68,71\%; TDN 60,95-76,53\% dan GE 4672,49 kal/g (Laboratorium Pengujian Nutrisi, Puslit Biologi LIPI 2010; Laboratorium Sumberdaya Hayati dan Bioteknologi IPB 2014).

Respon fisiologis merupakan indikator baik buruknya kondisi ternak yang dapat dipengaruhi oleh pakan dan temperatur lingkungan. Respon fisiologis yang tidak normal menandakan adanya gangguan terhadap kesehatan ternak dan dapat berpengaruh terhadap produktivitasnya. Pemberian pakan dengan sumber energi yang berbeda dapat mempengaruhi respon fisiologis ternak. Peningkatan produksi panas dalam tubuh akibat dari proses metabolisme pakan menyebabkan ternak akan mempertahankan temperatur tubuhnya melalui proses termoregulasi (Frandson 1992), sehingga ternak tetap dalam kondisi normal. Pelepasan panas tubuh ditandai dengan meningkatnya denyut jantung dan frekuensi napas. Peningkatan frekuensi napas bertujuan untuk membantu mengendalikan suhu tubuh. Suhu rektal merupakan respon terakhir dari gambaran kondisi fisiologis seekor ternak. Tujuan dari penelitian ini adalah untuk mengkaji pengaruh suplementasi ampas kurma terhadap respon fisiologis kambing PE laktasi (suhu rektal, frekuensi respirasi dan denyut jantung).

\section{MATERI DAN METODE}

Penelitian dilakukan di CV. Cordero Farm, Bogor, Indonesia. Penelitan ini menggunakan 9 (sembilan) kambing PE yang telah beranak satu kali, secara acak ditempatkan dalam kandang panggung individual. Berat badan rata-rata adalah $58,67 \pm 7,08 \mathrm{~kg}$ dan produksi susu 584,31 $\pm 31,51 \mathrm{ml} / \mathrm{hari}$. Ransum basal terdiri dari $35 \%$ hijauan dan $65 \%$ konsentrat (Tabel 1). Hijauan terdiri dari rumput Gajah dan pelet 
indigofera dan konsentrat dibuat dari limbah tempe kering, tepung kelapa, bekatul, premix, DCP dan kapur. Formulasi ransum berdasarkan pada kebutuhan kambing laktasi (NRC 2007), yaitu 14\% protein kasar dan 61\% TDN. Ransum iso-protein dan iso-energi di berbagai tingkat pemanfaatan ampas kurma (AK).

Kambing ditempatkan di kandang individu dengan bahan bambu dan kayu dengan ukuran rata-rata 2 x 1,5 meter. Pakan diberikan 3 kali sehari (jam 06.30, 14.00 dan 16.00 WIB) terdiri dari campuran konsentrat, ampas kurma dan hijauan dan minuman diberikan ad libitum.

\section{Respon fisiologis}

Respon fisiologis yang diukur meliputi suhu rektal, frekuensi respirasi dan denyut jantung. Suhu tubuh di ukur menggunakan termometer digital yang dimasukan ke dalam rektal sedalam $3-5 \mathrm{~cm}$.

Tabel 1. Komposisi pakan dan kandungan zat makanan ransum perlakuan (\% BK)

\begin{tabular}{|c|c|c|c|}
\hline \multirow{2}{*}{ Komposisi pakan } & \multicolumn{3}{|c|}{ Perlakuan } \\
\hline & T0 & $\mathrm{T} 1$ & $\mathrm{~T} 2$ \\
\hline Hijauan & 35,00 & 35,00 & 35,00 \\
\hline Rumput gajah & 25,00 & 25,00 & 25,00 \\
\hline Pelet indigofera & 10,00 & 10,00 & 10,00 \\
\hline Konsentrat & 65,00 & 55,00 & 45,00 \\
\hline Ampas tempe & 42,00 & 31,00 & 24,00 \\
\hline Bungkil kelapa & 15,68 & 16,36 & 18,84 \\
\hline Dedak padi & 5,23 & 5,45 & 0,00 \\
\hline Premix & 0,52 & 0,55 & 0,54 \\
\hline $\mathrm{DCP}$ & 0,52 & 0,55 & 0,54 \\
\hline $\mathrm{CaCO}_{3}$ & 1,05 & 1,09 & 1,08 \\
\hline Ampas kurma & 0,00 & 10,00 & 20,00 \\
\hline Total & 100,00 & 100,00 & 100,00 \\
\hline \multicolumn{4}{|l|}{ Komposisi nutrien* } \\
\hline Protein kasar $(\%)$ & 14,13 & 13,88 & 13,70 \\
\hline Lemak kasar (\%) & 5,17 & 5,03 & 4,48 \\
\hline Serat kasar (\%) & 18,64 & 26,43 & 25,70 \\
\hline $\begin{array}{l}\text { Total digestible } \\
\text { nutrien/TDN }(\%)^{2}\end{array}$ & 61,26 & 61,46 & 60,36 \\
\hline $\operatorname{BETN}(\%)^{1}$ & 44,08 & 46,10 & 47,57 \\
\hline
\end{tabular}

T0: $0 \%$ AK (kontrol); T1 : 10\% AK; T2 : 20\% AK

Sumber: *Hasil analisis Laboratorium Sumberdaya Hayati dan Bioteknologi PAU IPB (2014), ${ }^{1}$ Berdasarkan perhitungan $(\%)$ BETN $=100-[+(\%) \mathrm{Abu}+(\%) \mathrm{LK}+(\%) \mathrm{PK}+(\%) \mathrm{SK}]$, ${ }^{2} \mathrm{TDN}=37,937+1,018 \quad(\mathrm{SK})-4,886(\mathrm{LK}) \quad+0,173($ betaN $)+1,042(\mathrm{PK})+0,015(\mathrm{SK})^{2}$ $0,058(\mathrm{LK})^{2}+0,008(\mathrm{SK})($ beta-N $)+0,119(\mathrm{LK})($ beta-N $)+0,038(\mathrm{LK})(\mathrm{PK})+0,0039(\mathrm{LK})^{2}(\mathrm{PK})$

(Hartadi et al. 1990). 
Termometer akan memberi sinyal alarm saat suhu tubuh ternak telah terekam. Respirasi diukur dengan cara mendengarkan suara hembusan nafas dan melihat kembang kempisnya perut kambing selama 1 menit yang diulang sebanyak tiga kali. Denyut jantung diukur menggunkan stetoskop yang ditempelkan pada bagian dada sebelah kiri selama 1 menit dan diulang sebanyak tiga kali dengan bantuan stopwatch. Pengukuran respon fisiologis dilakukan pada pagi dan sore hari.

\section{Analisis data}

Penelitian menggunakan rancangan acak kelompok dengan pengelompokan induk kambing berdasarkan produksi susu, yaitu 3 perlakuan dan 3 ulangan. Perlakuan yang diterapkan, yaitu $\mathrm{T} 0=0 \%$ ampas kurma (kontrol); $\mathrm{T} 1=10 \%$ ampas kurma; dan $\mathrm{T} 2=$ $20 \%$ ampas kurma. Data status fisiologis ternak dianalisis dengan Analysis of Variance (ANOVA). Perlakuan yang menunjukkan perbedaan nyata pada level $\mathrm{P}<0,05$ dilanjutkan dengan Uji Duncan.

\section{HASIL DAN PEMBAHASAN}

\section{Konsumsi pakan}

Rata-rata konsumsi dan kecernaan energi pakan kambing PE yang memperoleh suplementasi ampas kurma seperti pada Tabel 2. Analisis statistik menunjukkan bahwa peningkatan penggunaan ampas kurma dalam ransum menurunkan konsumsi bahan kering dan energi secara linear. Rata-rata konsumsi bahan kering dan energi paling tinggi pada perlakuan T0 berturut-turut sebesar 1,67 kg/ekor dan 5.178,37 kcal/ekor/hari. Penambahan ampas kurma dapat menurunkan konsumsi bahan kering pada ternak dibandingkan dengan ransum kontrol. Hal ini terjadi karena ampas kurma sebagai sumber energi memberikan sumbangsih terbesar terhadap ketersediaan karbohidrat non serat atau BETN. Komponen BETN yang terkandung dalam ransum perlakuan T2 relatif lebih tinggi dibandingkan T1 dan T0 (kontrol). Bradford \& Allen (2007) dan Iva et al. (2006) melaporkan bahwa BETN adalah prekursor pembentukan propionat, peningkatan konsentrasi propionat dapat memicu meningkatnya konsentrasi glukosa plasma, sehingga memberikan signal rasa kenyang ke hipotalamus (nucleus ventromedial) dan membuat nafsu makan menurun. Faktor-faktor lain yang dapat mempengaruhi konsumsi BK yakni palatabilitas, kemampuan ternak dalam mencerna pakan, serta status kesehatan ternak (Lubis 1992).

Tabel 2. Performa kambing PE yang diberi rasum berbasis ampas kurma

\begin{tabular}{lcccc}
\hline \multirow{2}{*}{ Parameter } & \multicolumn{3}{c}{ Perlakuan } & SEM \\
\cline { 2 - 4 } & T0 & T1 & T2 & \\
\hline Konsumsi BK (kg/ekor/hari) ${ }^{1)}$ & 1,67 & 1,48 & 1,21 & 0,09 \\
Konsumsi energi (kcal/ekor/hari) & $5.178,37$ & $4.502,26$ & $3.677,59$ & 279,35 \\
Kecernaan energi $(\%)^{2)}$ & 68,54 & 75,80 & 56,74 & \\
Energi metabolisme $(\%)^{2)}$ & 67,72 & 75,08 & 56,16 & \\
\hline
\end{tabular}

Sumber: ${ }^{1)}$ Yuniarti (2016); ${ }^{2)}$ data diolah dari Yuniarti (2016); T0 = 0\% AK (kontrol); T1 = $10 \% \mathrm{AK} ; \mathrm{T} 2=20 \% \mathrm{AK}$ 
Nutrien yang masuk ke dalam tubuh ternak sebagian besar akan dicerna untuk dijadikan sebagai energi utama ruminansia dan yang lainnya akan terbuang melalui feses. Pengaruh pengunaan ampas kurma terhadap kecernaan kambing PE seperti Tabel 2. Hasil penelitian menunjukkan bahwa ransum dengan kandungan ampas kurma $10 \%$ relatif memiliki persentase kecernaan paling tinggi, yaitu 75,80\%, akan tetapi saat kambing disuplementasi ampas kurma $20 \%$ memiliki persentase kecernaan energi paling rendah. Respon ini dapat terjadi karena penggunaan ampas kurma menyebabkan penurunan $\mathrm{pH}$ rumen, sehingga mampu mempercepat proses fermentasi di rumen. Namun demikian, pada penggunaan ampas kurma $20 \%$ diduga dapat menurunkan $\mathrm{pH}$ rumen hingga batas kisaran optimal (nilai $\mathrm{pH}$ optimal 6,5). Penurunan $\mathrm{pH}$ rumen hingga $\leq 6,1$ bias terhadap penurunan kecernaan serat akibat terhambatnya aksi mikroorganisme selulolitik seperti ruminococcus dan fibrobacter (Zhang et al. 2017). Menurut Susanti \& Marhaeniyanto (2007) bahwa komposisi ransum, bentuk fisik dari ransum, jumlah ransum yang diberikan dan kandungan nutrisi pakan mempengaruhi kecernaan pakan.

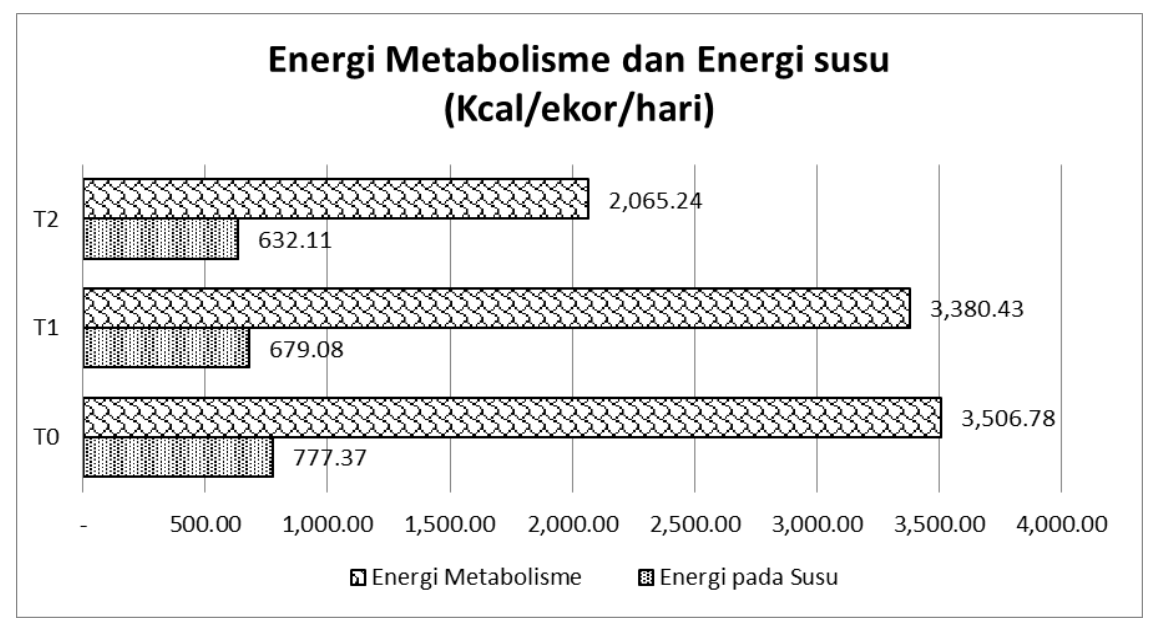

Gambar 1.Energi metabolisme dan energi susu kambing PE dengan ransum berbasis ampas kurma (Sumber: Yuniarti 2016)

Energi pakan yang dicerna selanjutnya akan dimetabolis dan diubah bentuk menjadi energi yang berguna untuk tubuh dan disimpan untuk menunjang pertumbuhan dan produksi, dan sebagian energi yang tidak berguna akan dibuang dalam bentuk panas tubuh. Pengaruh pengunaan ampas kurma terhadap metabolisme energi kambing PE (Tabel 2), menunjukkan terjadi kehilangan energi sebesar 24,20-43,26\% dari total energi yang dikonsumsi dan kehilangan energi pada proses metabolisme berkisar antara 0,58 $0,82 \%$ dari total energi tercerna. Astuti \& Sumiati (2013) menjelaskan bahwa proses fermentasi di dalam rumen membutuhkan energi setidaknya 5-10\% dari total energi bruto (pakan) dan produksi panas yang terbentuk harus dikeluarkan agar tidak terjadi heat schock (cekaman panas). Penambahan ampas kurma masuk ke dalam tubuh ternak dapat menurunkan heat increament pada proses metabolisme. Ransum dengan perlakuan suplementasi ampas kurma 10\% (T1) memiliki energi termetabolis paling efisien. Penggunaan energi pakan yang dimetabolisme kambing PE yang disuplementasi ampas kurma seperti di Gambar 1. Proporsi retensi energi untuk susu pada perlakuan T0, T1, T2 berturut-turut sebesar 22,17, 20,09 dan 30,61\% dari energi metabolisme ternak (Yuniarti 2016). Sedangkan sisanya pada tiap perlakuan sebesar 77,83, 79,91 dan 69,39\% diduga digunakan untuk kontraksi otot, mempertahankan suhu dan menghantar impul. 
Kecenderung meningkatnya proporsi retensi energi pada susu seiring dengan meningkatnya level suplementasi ampas kurma dipengaruhi oleh peningkatan asam propionat (Yuniarti 2016).

\section{Respon fisiologis (denyut jantung, frekuensi respirasi, dan suhu rektal)}

Respon fisiologis ternak pada kambing PE yang memperoleh suplementasi ampas kurma disajikan pada Tabel 3. Analisis statistik menunjukkan bahwa perlakuan tidak berpengaruh nyata terhadap respon fisiologis ternak. Rata-rata denyut nadi, frekuensi napas dan suhu rektal kambing PE berturut-turut sebesar 81,11-91,05 kali/menit, 27,27$58,13 \mathrm{kali} / \mathrm{menit}$ dan 38,62-39,04 ${ }^{\circ} \mathrm{C}$. Qiston \& Suharti (2005) melaporkan bahwa respon fisiologis kambing PE yang diberi naungan, yaitu denyut jantung 86,6 kali/menit, frekuensi napas $67,6 \mathrm{kali} / \mathrm{menit}$ dan suhu rektal $38,7^{\circ} \mathrm{C}$. Rataan denyut jantung kambing dewasa $67-95 \mathrm{kali} / \mathrm{menit}$, suhu rektal $38,5-40^{\circ} \mathrm{C}$ dan frekuensi respirasi $15-30 \mathrm{kali} / \mathrm{menit}$ (Yusuf 2007; Hamzaoui 2013). Respon fisiologis kambing PE yang mendapat suplementasi ampas kurma dalam kondisi normal meskipun relatif berubahnya pola proporsi ransum terkonsumsi. Tresia et al. (2015) melaporkan bahwa penggunaan tepung daun kemuning dalam ransum kambing PE laktasi berbasis ampas kurma 10\% tidak mempengaruhi respon fisiologis (denyut jantung, frekuensi respirasi, dan suhu rektal). Respon ini menunjukkan bahwa kambing telah mengaktifkan sistem termoregulasi tubuhnya untuk menjaga suhu tubuh tetap konstan, dengan jalan membuang panas melalui pernafasan. Ada kecenderungan kambing PE yang disuplementasi ampas kurma menunjukkan frekuensi pernapasan dan suhu rektal yang lebih tinggi. Hal tersebut berkaitan dengan aktivitas metabolisme, dimana produksi panas yang tinggi mengakibatkan aktivitas metabolisme yang lebih cepat dibandingkan kambing dengan produksi panas yang rendah. Suherman \& Purwanto (2015) bahwa pakan yang dikonsumsi ternak bisa berpengaruh meningkatkan laju produksi panas dalam tubuh atau disebut juga dengan efek kalorigenik pakan dan untuk mempertahankan kondisi homeostasis. Menurut Yani \& Purwanto (2006), peningkatan denyut jantung dan pernafasan akan mempercepat aliran panas tubuh ke permukaan tubuh yang selanjutnya dikeluarkan ke lingkungan melalui konduksi, konveksi, radiasi maupun evaporasi, sehingga suhu tubuh relatif konstan. Pelepasan panas tubuh ke luar tubuh dengan cara memindahkan panas dari organ-organ bagian dalam tubuh ke bagian-bagian terluar dari organ tubuh terutama adalah kelenjar keringat di kulit dan kelenjar mukosa di sepanjang saluran pernafasan (Ganong 1983).

Tabel 3. Rataan respon fisiologi kambing PE

\begin{tabular}{llccc}
\hline \hline \multirow{2}{*}{ Parameter } & Waktu & \multicolumn{3}{c}{ Perlakuan } \\
\cline { 3 - 5 } & & T0 & T1 & T2 \\
\hline Denyut Jantung & Pagi & $81,11 \pm 8,68$ & $89,96 \pm 11,03$ & $84,60 \pm 12,43$ \\
(kali/menit) & Sore & $92,99 \pm 10,67$ & $91,38 \pm 8,10$ & $91,05 \pm 10,73$ \\
Frekuensi Napas & Pagi & $27,27 \pm 6,99$ & $37,22 \pm 10,77$ & $39,83 \pm 13,44$ \\
(kali/menit) & Sore & $41,22 \pm 12,14$ & $57,08 \pm 16,40$ & $58,13 \pm 17,94$ \\
Suhu Rektal $\left({ }^{\circ} \mathrm{C}\right)$ & Pagi & $38,62 \pm 0,20$ & $38,66 \pm 0,18$ & $38,74 \pm 0,16$ \\
& Sore & $39,01 \pm 0,18$ & $38,95 \pm 0,22$ & $39,04 \pm 0,19$ \\
\hline
\end{tabular}

T0: 0\% AK (kontrol); T1 : 10\% AK; T2 : 20\% AK 


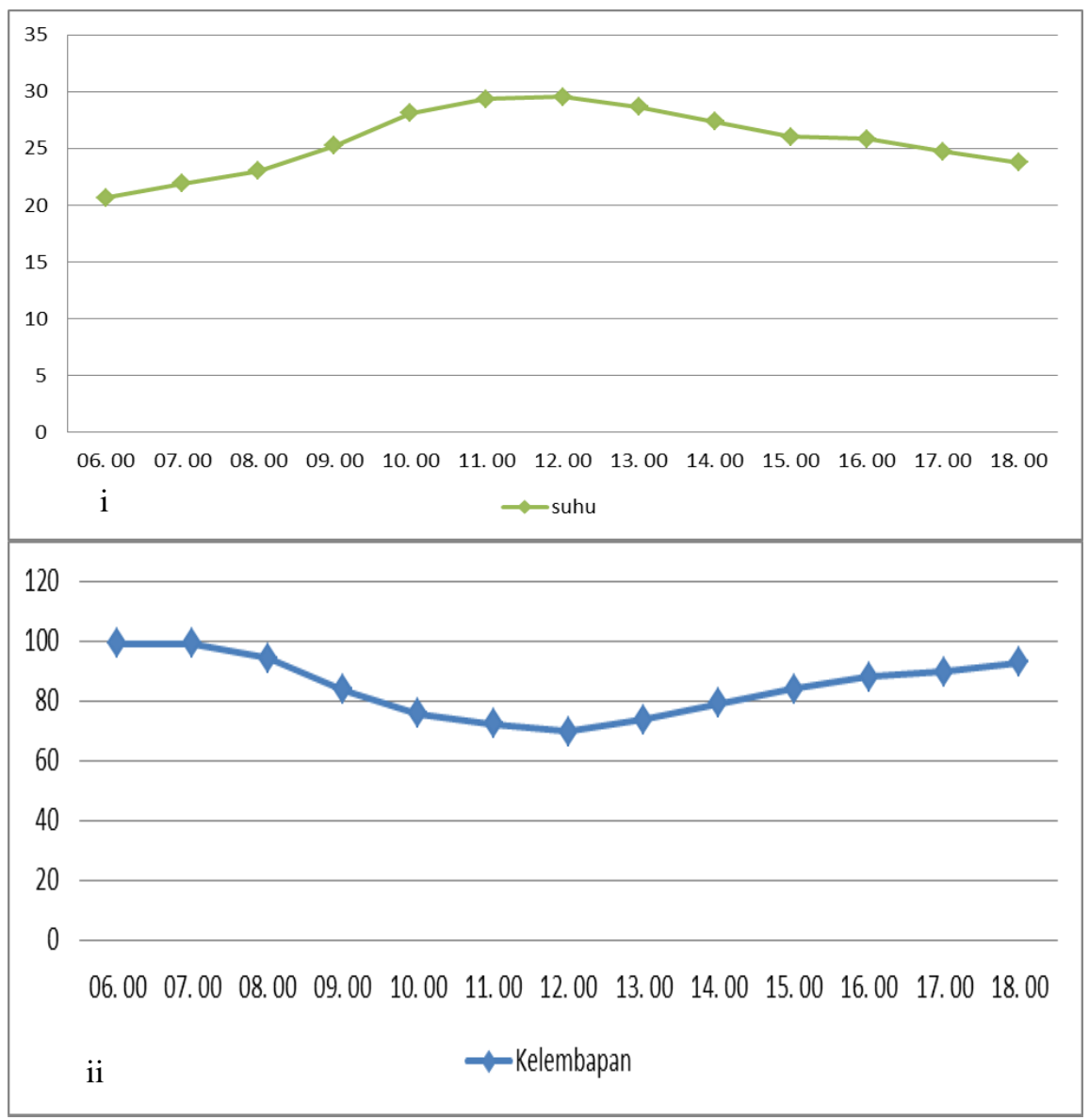

Gambar 2. (i) Suhu (ii) dan kelembapan kandang

Kondisi lingkungan yang nyaman (thermoneutral zone) akan mendukung kelangsungan hidup ternak secara efisien. Respon fisiologis ternak tidak hanya dipengaruhi oleh pakan tetapi juga bisa dipengaruhi oleh keadaan lingkungan. Pengaruh kodisi suhu dan kelembapan dalam kandang akan mempengaruhi respon fisiologis ternak kambing PE. Wiliamson \& Payne (1993) menyatakan kondisi mikroklimat optimum di wilayah tropis adalah suhu $18-21^{\circ} \mathrm{C}$ dan kelembapan $50-60 \%$. Hasil penelitian Smith dan Mangkuwidjojo (1988) menjelaskan bahwa kambing memerlukan suhu optimum antara $18-30^{\circ} \mathrm{C}$ untuk menunjang produksinya. Suhu mikroklimat kandang, selama 39 hari pemeliharaan, yaitu $18-32,9^{\circ} \mathrm{C}$ dan kelembapannya $48-99 \%$. Kondisi di atas mikroklimat yang optimum ini dapat mempengaruhi respon fisiologis ternak untuk menyeimbangkan panas tubuh. Suhu mikroklimat sore hari lebih tinggi dan kelembapannya lebih rendah dibandingkan dengan suhu dan kelembapan pagi hari. Kondisi tersebut mengakibatkan respon fisiologis ternak pada sore hari meningkat, yaitu denyut jantung, frekuensi respirasi dan suhu rektal kambing PE. 


\section{KESIMPULAN}

Suplementasi pakan berbasis ampas kurma tidak mempengaruhi denyut jantung, frekuensi respirasi, dan suhu rektal. Kondisi fisiologis kambing PE pada penelitian ini masih dalam kondisi normal. Penggunaan ampas kurma 10\% memberikan pengaruh positif terhadap tingkat kecernaan dan metabolisme energi. Berdasarkan hasil penelitian, dapat disimpulkan bahwa penggunaan ampas kurma 10\% dalam ransum dapat digunakan sebagai alternatif pakan untuk kambing perah yang laktasi.

\section{DAFTAR PUSTAKA}

Astuti DA, Sumiati. 2013. Bioenergi ternak tropika. \{Internet]. [cited 23 Juli 2019]. Available from: https://repository.ipb.ac.id/jspui/bitstream/123456789/78915/1/ART2014_DAA. pdf.

Badan Pusat Statistik 2017. Statistik peternakan. [Internet]. [cited 25 Juli 2019]. Available from: www.bps.go.id/statictable/2017/12/06/1980.

Frandson RD. 1992. Anatomi dan fisiologi ternak. Edisi ke-4. Yogyakarta (Indonesia): Gadjah Mada University Press.

Ganong. 1983. Receive of logical physiology. California (US): Large Medical Publishing.

Hamzaoui S, Salama AAK, Such X, Caja G. 2013. Physiological responses and lactational performances of late-lactation dairy goats under heat stress conditions. J Dairy Sci. 96:111.

Iva T, Wahono D, Handayani D. 2006. Pengaruh pemberian diet tinggi karbohidrat dibandingkan diet tinggi lemak terhadap kadar trigliserida dan hdl darah pada rattus novergicus galur wistar. J Kedokteran Brawijaya. 22:80-89.

Lubis DA. 1992. Ilmu makanan ternak. Jakarta (Indonesia): PT Pembangunan.

Newbold CJ, Lopez S, Nelson N, Ouda JO, Wallace RJ, Moss AR. 2005. Propionate precursors and other metabolic intermediates as possible alternative electron acceptors to methanogenesis in ruminal fermentation in vitro. Br J Nutr. 94:27-35.

National Research Council 2007. Nutrient requirements of small ruminant. Washington DC (USA): National Academy Press.

Qisthon A, Suharti S. 2005. Pengaruh naungan terhadap respon termoregulasi dan produktivitas kambing peranakan etawah. Media Peternakan. 7:505-502.

Smith JB, Mangkoewidjojo S. 1988. Pemeliharaan, pembiakan dan penggunaan hewan percobaan di daerah tropis. Jakarta (Indonesia): UI Press.

Suherman D, Purwanto BP. 2015. Respon fisiologis sapi perah dara Fries Holland yang diberi konsentrat dengan tingkat energi berbeda. J Sains Peternakan Indonesia. 10:13-21.

Susanti S, Marhaeniyanto E. 2007. Kecernaan, retensi nitrogen dan hubungannya dengan produksi susu pada sapi peranakan Friesian Holstein $(\mathrm{PFH})$ yang diberi pakan pollard dan bekatul. J Protein 15:141-147.

Sutama IK. 2011. Innovation technology in reproduction for the development of local dairy goats. Pengembangan Inovasi Pertanian. 4:231-246.

Tresia GE, Evvyernie D, Herlina E, Sukria HA. 2015. Benefit of kemuning leaves meal in ration containing dates fruit waste to suppress gastrointestinal parasites infestation of goats. In: Wiryawan IKG, editor. Proceeding the 3nd International Seminar Animal Industry. Bogor (Indonesia): Bogor Agricultural University. p. 352-354. 
Wiliamson J, Payne WJA. 1993. Pengantar peternakan di daerah topis. Yogyakarta (Indonesia): Gadjah Mada Universitas Press.

Yani A, Purwanto BP. 2006. Pengaruh iklim mikro terhadap respons fisiologis sapi peranakan Fries Holland dan modifikasi lingkungan untuk Meningkatkan produktivitasnya (Ulasan). Media Peternakan. 29:35-46.

Yousef MK. 2007. Thermoneutral zone. In: Yousef MK, editors. Stress physiology in livestock. Florida (USA): CRC Press.

Yuniarti E, Evvyernie E, Astuti DA. 2015. Production and energy partition of lactating dairy goats fed rations containing date fruit waste. Media Peternakan. 39:27-33.

Zhang L, Jongshik C, Jianga Q, Suna R, Zhang J, Zhong Y, Ren N. 2017. Characteristics of rumen microorganisms involved in anaerobic degradation of cellulose at various $\mathrm{pH}$ values. RSC Adv. 7:40303-40310. 